\title{
OctylPhenol (OP) Alone and in Combination with NonylPhenol (NP) Alters the Structure and the Function of Thyroid Gland of the Lizard Podarcis siculus
}

\author{
Rosaria Sciarrillo ${ }^{1}$ Mariana Di Lorenzo ${ }^{2}$. Salvatore Valiante ${ }^{2}$ Luigi Rosati $^{2}$ Maria De Falco Ma, $^{2,4}$
}

Received: 1 November 2020 / Accepted: 19 February 2021 / Published online: 9 March 2021

(c) The Author(s) 2021

\begin{abstract}
Different environmental contaminants disturb the thyroid system at many levels. AlkylPhenols (APs), by-products of microbial degradation of AlkylPhenol Polyethoxylates (APEOs), constitute an important class of Endocrine Disrupting Chemicals (EDCs), the two most often used environmental APs being 4-nonylphenol (4-NP) and 4-tert-octylphenol (4-t-OP). The purpose of the present study was to investigate the effects on the thyroid gland of the bioindicator Podarcis siculus of OP alone and in combination with NP. We used radioimmunoassay to determine their effects on plasma 3,3',5-triiodo-L-thyronine $\left(\mathrm{T}_{3}\right), 3,3^{\prime}, 5,5^{\prime}$-L-thyroxine $\left(\mathrm{T}_{4}\right)$, thyroid-stimulating hormone (TSH), and thyrotropin-releasing hormone (TRH) levels in adult male lizards. We also investigated the impacts of AP treatments on hepatic 5'ORD (type II) deiodinase and hepatic content of $\mathrm{T}_{3}$ and $\mathrm{T}_{4}$. After $\mathrm{OP}$ and $\mathrm{OP}+\mathrm{NP}$ administration, $\mathrm{TRH}$ levels increased, whereas $\mathrm{TSH}, \mathrm{T}_{3}$, and $\mathrm{T}_{4}$ levels decreased. Lizards treated with $\mathrm{OP}$ and $\mathrm{OP}+\mathrm{NP}$ had a higher concentration of $\mathrm{T}_{3}$ in the liver and 5'ORD (type II) activity, whereas $\mathrm{T}_{4}$ concentrations were lower than that observed in the control group. Moreover, histological examination showed that the volume of the thyroid follicles became smaller in treated lizards suggesting that that thyroid follicular epithelial cells were not functionally active following treatment. This data collectively suggest a severe interference with hypothalamus-pituitary-thyroid axis and a systemic imbalance of thyroid hormones.
\end{abstract}

Rosaria Sciarrillo

sciarrillo@unisannio.it

1 Department of Science and Technologies, University of Sannio, Benevento, Italy

2 Department of Biology, University of Naples "Federico II", Naples, Italy

3 National Institute of Biostructures and Biosystems (INBB), Rome, Italy

4 Center for Studies On Bioinspired Agro-Environmental Technology (BAT Center), Portici, Italy 


\section{Graphic Abstract}

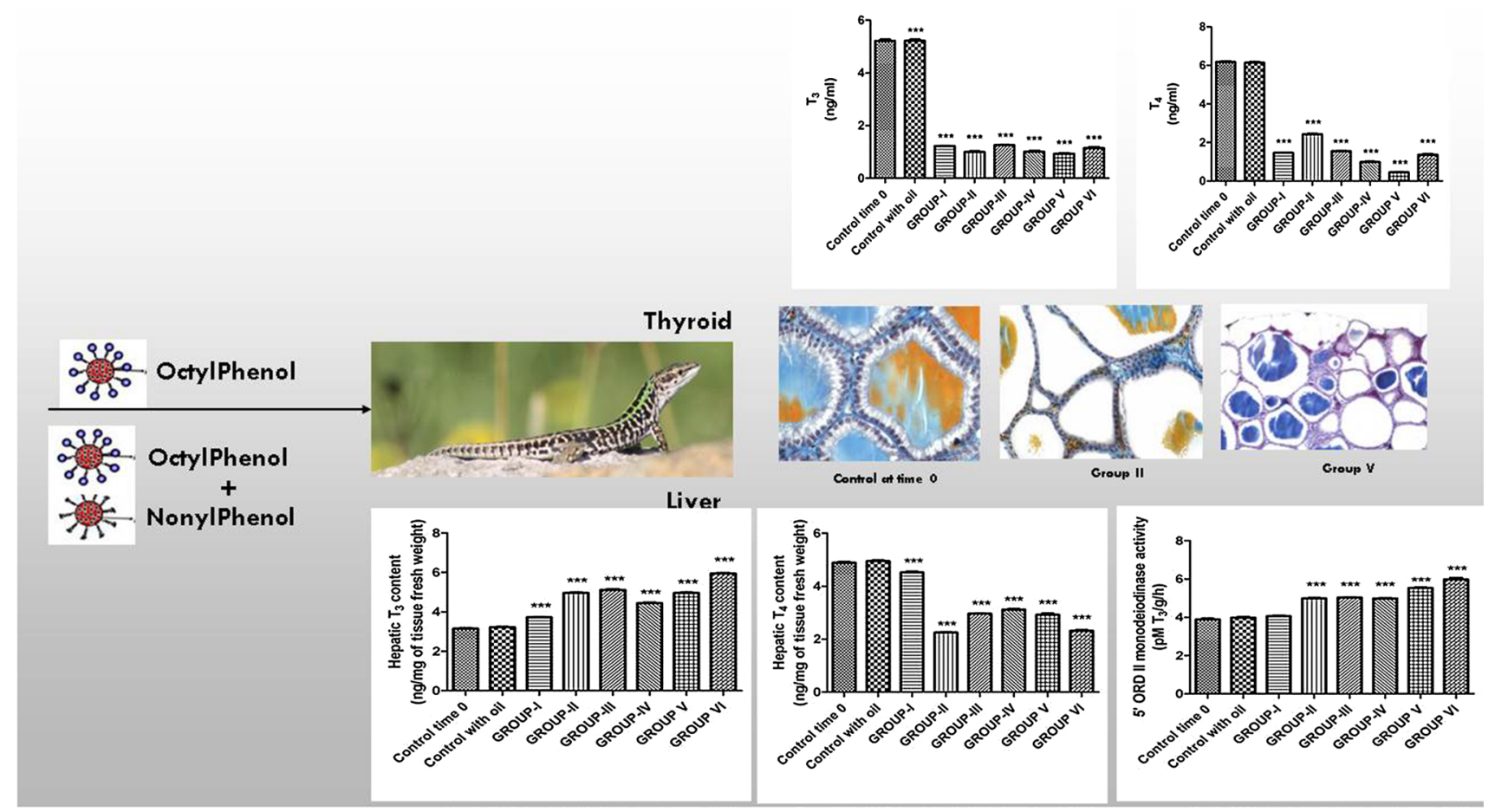

Thyroid is a gland with an endocrine activity and a follicular organization. This gland secretes thyroid hormones (THs), and its secretory activity is regulated by the thyroid-stimulating hormone (TSH) secreted by the anterior pituitary gland, which in turn is regulated by the thyrotropin-releasing hormone (TRH) produced by the hypothalamus. This hormonal crosstalk plays a pivotal role in the regulation of thyroid function (Esposito et al. 2015; Hay et al. 2019). The two main thyroid hormones are 3,3',5,5'-L-thyroxine $\left(\mathrm{T}_{4}\right)$ and the active 3,3',5-triiodo-L-thyronine $\left(\mathrm{T}_{3}\right)$ (Esposito et al. 2019; Perna et al. 2018) through which thyroid regulates protein synthesis, metabolism, growth, and rate of function of many other systems present in the body (Ji et al. 2012; Santangelo et al. 2016).

The incidence of thyroid diseases has continuously increased in recent years (Tingi et al. 2016), and it seems to correlate to exposure to several environmental pollutants, such as endocrine-disruptor chemicals (EDCs) (Benedetti et al. 2017; Djordjevic et al. 2020).

EDCs are a broad group of persistent and lipophilic compounds detected in different environmental matrices, able to bioaccumulate in animals and humans, and thus interfering temporarily or permanently with the hormonal signaling pathways in the endocrine system. As a consequence, they adversely affect different organs by binding to hormone receptors or interfering with the production, metabolism, and transfer of hormones and/or modifying gene expression (Ghassabian and Trasande 2018). Literature has extensively described the harmful effects of exposure to different EDCs in different organisms at multiple levels. For instance, the pesticide mancozeb, which has been shown to induce neurodegenerative effects in marine teleosts (Zizza et al. 2017, 2018), is considered to act as an oxidative stressor of both gills and blood (Kubrak et al. 2012) and an inductor of oxidative damage of lipids and proteins in brain, liver, and kidney of fishes (Atamaniuk et al. 2013). Mancozeb also exerts numerous injurious effects related to the function of the thyroid gland (Axelstad et al 2011; Goldner et al 2010). Additionally, several reports suggested a xenoestrogenic activity of alkylphenols (APs), such as Bisphenol A (BPA), NonylPhenol (NP), an OctylPhenol (OP) (Acconcia et al. 2017; Forte et al. 2016, 2019; In et al. 2015; Liu et al. 2017). These substances are largely used in industry to optimize the production of different products, such as herbicides, pesticides, lubricants, plastics, and personal care products (Asimakopoulos et al. 2012; Raecker et al. 2011). Their wide use has determined their detection in many environmentally relevant matrices as wastewaters, surface waters, sediments, and soil (Kung et al. 2018). Moreover, they have been detected in several aquatic species (Staniszewska et al 
2017) and in human blood samples, including amniotic fluid, urine, breast milk, fetal cord serum, and placenta (Ademollo et al. 2008; Calafat et al. 2007; Shekhar et al. 2017). APs are effective not only on reproductive system, but also can have neurotoxic effects on organisms (Liu et al. 2019), affect adrenal glands (De Falco et al. 2010, 2014; Di Lorenzo et al. 2020a, 2020b), or inhibit cell proliferation in gastric adenocarcinoma (Manente et al. 2011).

Some interesting evidence highlighted the impact of APs on thyroid. BPA, among its different mode of actions, affects the hypothalamic-pituitary-thyroid axis (HPT) both in vitro and in vivo (Benedetti et al. 2017; Fernandez et al. 2018; Moriyama et al. 2002; Tan et al. 2003; Wetherill et al. 2007; Zoeller et al. 2005).

Few studies investigated the effects of NP and OP on HPT, suggesting that both chemicals are capable of interfering with its function and, consequently, influence basic growth as well as development (Göktekin and Barlas 2008; He et al. 2019; Naderi et al. 2014; Wang et al. 2019; Xi et al 2013).

We have already demonstrated in a previous study that acute exposure to NP affects the function of thyroid glands in adult male lizard Podarcis siculus (Sciarrillo et al. 2010). The purpose of the present study was to evaluate the effects on the thyroid gland of the lizard species Podarcis siculus of OP, administered alone or combined to NP. P. siculus was chosen for this study, because it is a sentinel species for biomonitoring the ecotoxicological impact of EDCs, due to its ecological and life history characteristics, such as its distribution in a variety of habitats, wide geographical range, longevity, site fidelity (i.e., philopatric), and high sensitivity to the effects of contaminants (Verderame et al. 2016a,b).

The effects of $\mathrm{OP}$ and $\mathrm{OP}+\mathrm{NP}$ exposure on $\mathrm{T}_{3}, \mathrm{~T}_{4}, \mathrm{TSH}$, and TRH plasma levels in adult lizards were determined by radioimmunoassay. Hepatic $\mathrm{T}_{3}$ and $\mathrm{T}_{4}$ contents and deiodinase types II (5'ORD2) activity also was investigated to identify the effect of OP and OP + NP on the liver, which is the principal target organ of THs. Besides, we investigated the histological changes of the thyroid glands.

\section{Materials and Methods}

\section{Compounds}

OctylPhenol (OP) and NonylPhenol (NP) were obtained from FLUKA (Sigma-Aldrich Co., St. Louis, MO) (ECHA 2019 , n.d.).

\section{Animals and Housing Conditions}

Adult specimens of Podarcis siculus, weighing 13-15 g, were live-captured in the neighborhood of Naples in June when their thyroid gland was in full functional activity (Sciarrillo et al. 2000). Lizards were maintained in a soil-filled terrarium containing heather and indoor exposed to natural photoperiod and temperature. They were fed with Tenebrio molitor larvae and water dishes were always available in the terraria. Before starting the treatments, an acclimatization period of approximately 15 days was allowed to reverse capture-related stress (Rosati et al. 2020). The experiments were performed in accordance with the ethical provisions imposed by the European Union and permitted by the National Committee of the Italian Ministry of Health on in vivo experimentation.

\section{Experimental Procedure}

Podarcis siculus specimens were treated with $\mathrm{OP}$ and $\mathrm{OP}+\mathrm{NP}$. Compound concentrations administered were established based on preliminary dose-response tests and data (De Falco et al. 2014; Di Lorenzo et al. 2020b; Sciarrillo et al. 2010).

Lizards were divided into eight groups ( 6 treated and 2 control groups), each consisting of ten animals (5 males and 5 females). OP was used at the concentration of $0.161 \mu \mathrm{g}$ and $\mathrm{NP}$ at $0.172 \mu \mathrm{g}$; both compounds were dissolved in $50 \mu \mathrm{L}$ of corn oil and administered through intraperitoneal injections every 2 days. Lizards were daily inspected for signs of toxicity and death.

Control Group: Untreated control lizards were sacrificed after having been housed for 20 days in nonpolluted terraria (time zero controls); an additional control group (group treated with oil) was intraperitoneally injected with $50 \mu \mathrm{L}$ of corn oil for 22 times. From this group, five lizards were sacrificed $24 \mathrm{~h}$ after the last injection and five 15 days after last injection.

Study Group I: Lizards were treated with 12 intraperitoneal injections of OP and sacrificed $24 \mathrm{~h}$ after the last injection.

Study Group II: Lizards were treated with 22 intraperitoneal injections of OP and sacrificed $24 \mathrm{~h}$ after the last injection.

Study Group III: Lizards were treated with 22 intraperitoneal injections of OP and sacrificed 15 days after the last injection (recovery OP group).

Study Group IV: Lizards were treated with 10 intraperitoneal injections of OP $+\mathrm{NP}$ and sacrificed $24 \mathrm{~h}$ after the last injection.

Study Group V: Lizards were treated with 17 intraperitoneal injections of OP $+\mathrm{NP}$ and sacrificed $24 \mathrm{~h}$ after the last injection.

Study Group VI: lizards were treated with seventeen (17) intraperitoneal injections of $\mathrm{OP}+\mathrm{NP}$ and sacrificed 15 days after the last injection (recovery OP $+\mathrm{NP}$ group). 
Lizards were anesthetized and sacrificed by decapitation immediately after collection of blood samples the day after the last injection.

\section{Hormone Assay}

Blood samples were collected by intracardiac puncture and put into heparinized tubes. Plasma for hormonal dosages was obtained by centrifuging blood samples for $10 \mathrm{~min}$ at $1,500 \mathrm{rpm}$ at $4{ }^{\circ} \mathrm{C}$. TRH and TSH levels were determined by immunoradiometric assay (IRMA) as previously reported by Sciarrillo et al. (2009). $\mathrm{T}_{3}$ and $\mathrm{T}_{4}$ levels were determined using radioimmunoassay (RIA) (Sciarrillo et al. 2009, 2010).

\section{Hepatic Thyroid Hormones $\left(\mathrm{T}_{4}\right.$ and $\left.\mathrm{T}_{3}\right)$ Content and 5-T4 ORD (type II) Monodeiodinase Activity}

Livers were removed and rinsed in a buffer composed by

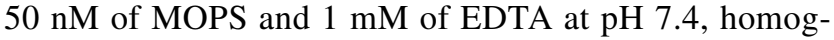
enized in sucrose buffer $(0.25 \mathrm{M}$ sucrose, $5 \mathrm{mM}$ Tris, $\mathrm{pH}$ 8.0) using a Pyrex tissue grinder held on ice. Homogenate was then centrifuged at $4{ }^{\circ} \mathrm{C}$ and $1,000 \mathrm{rpm}$ for $10 \mathrm{~min}$. Pellet was suspended in sucrose buffer and centrifugated again, whereas supernatant was centrifugated at $4{ }^{\circ} \mathrm{C}$ and $12,000 \mathrm{rpm}$ for $5 \mathrm{~min}$. The resulting final supernatant (premicrosomal fraction) was centrifugated in an ultracentrifuge at $4{ }^{\circ} \mathrm{C}$ and $78,000 \mathrm{rpm}$ for $90 \mathrm{~min}$. Microsomal pellets were suspended in MOPS and stored at $-80^{\circ} \mathrm{C}$. The content of $\mathrm{T}_{3}$ and $\mathrm{T}_{4}$ in hepatic tissue was determined by RIA and was expressed as ng/mg of tissue (fresh weight) (Sciarrillo et al. 2000). Thirty microliters of the homogenate was incubated at $12{ }^{\circ} \mathrm{C}$ for 20 min with 3 volumes of buffer containing $50 \mathrm{mM}$ of 1-4 dithio-DL-threitol (DTT) and $1 \mathrm{nM}$ radiolabeled T4. Cold ethanol was added to the samples, which were kept at $4{ }^{\circ} \mathrm{C}$ overnight, and then centrifugated at $4{ }^{\circ} \mathrm{C}$ and $1400 \mathrm{rpm}$ for $20 \mathrm{~min}$. Supernatant was used to determine 5'-T4 ORD type II (ORD II) monodeiodinase activity, expressed as $\mathrm{pM} \mathrm{T}_{3} / \mathrm{g}$ (of liver)/h (Sciarrillo et al. 2000).

\section{Light Microscopy}

Animals were anaesthetized by hypothermia and decapitated. Thyroid glands were removed and immediately fixed in Bouin's fixative and processed for light microscopy (LM) observation. Serially cut paraffin sections $(7 \mu \mathrm{m})$ were stained with Galgano stain and observed using a Zeiss Axioskop microscope. The height of the follicular cells was measured in 30 cells always using the second section of both normal and treated samples every three slides, using a digital system of image (KS 300).

\section{Statistical Analysis}

Statistical analysis was performed using the GraphPad Prism 8 software. Data obtained were expressed as means \pm standard error of mean (SEM). Experimental data of all the groups was tested together for significance using one-way ANOVA, followed by Bonferroni's multiple comparison test. Differences were considered statistically significant when the $p$ value was at least $p<0.05$.

\section{Results}

\section{Sign of Toxicity and Animal Mortality}

Sign of toxicity and mortality of the animal were continuously monitored during the experiment. Lizards from groups treated with OP alone or combined to NP showed evident signs of toxicity and mortality (Table 1). Interestingly, lizards remained in groups on the bottom of the terraria moving very slowly when treated with OP.

The effect of OP seemed to correlate with the duration of treatment. Lizards treated with OP (Study Group I) showed dyspnea after 12 intraperitoneal injections, whereas animals from study Group II and III showed hindlimb paralysis after 22 intraperitoneal injections of OP (Table 1). A similar pattern of toxicity was observed in all the groups of lizards treated with the mixture of OP and NP. A mortality of $20 \%$ was observed in lizards treated with OP + NP both after 10 and 17 i.p. injections (Table 1). No significant body weight changes were noticed between control and study groups (data not shown).

Table 1 Mortality and signs of toxicity of specimens of Podarcis sicula treated with OP and OP + NP mixture (see Materials and Methods section)

\begin{tabular}{lll}
\hline Treatments & $\begin{array}{l}\text { Dead animals (\% of } \\
\text { animal mortality) }\end{array}$ & Signs of toxicity \\
\hline Control time 0 & 0 & None \\
Control with oil & 0 & None \\
OP treated & & Dyspnea \\
Group I & 0 & Dyspnea, hind-limb paralysis \\
Group II & $2(10 \%)$ & Dyspnea, hind-limb paralysis \\
Group III & $2(10 \%)$ & Dyspnea, hind-limb paralysis \\
OP + NP treated & & Dyspnea, hind-limb paralysis \\
Group IV & $4(20 \%)$ & Dyspnea, hind-limb paralysis \\
Group V & $4(20 \%)$ & \\
Group VI & $4(20 \%)$ &
\end{tabular}




\section{Hormone Plasma Levels}

Lizards treated with 12 injections of OP (Study Group I) showed an almost three-time increase in TRH level compared with control group $(8.03 \pm 0.40 \mu \mathrm{UI} / \mathrm{mL}$ vs. $3.15 \pm 0.16 \mu \mathrm{UI} / \mathrm{mL}$ ) (Table 2; Fig. 1a). In contrast, TSH plasma level decreased from $7.23 \pm 0.36 \mu \mathrm{UI} / \mathrm{mL}$ (Control group) to $3.21 \pm 0.16 \mu \mathrm{UI} / \mathrm{mL}$ (Group I) (Table 2; Fig. 1b). $\mathrm{T}_{3}$ and $\mathrm{T}_{4}$ values also were reduced, $\mathrm{T}_{3}$ passing from $5.21 \pm 0.26 \mathrm{ng} / \mathrm{mL}$ (Control group) to $1.22 \pm 0.06 \mathrm{ng} / \mathrm{mL}$ (Group I), and $\mathrm{T}_{4}$ from $6.18 \pm 0.31 \mathrm{ng} / \mathrm{mL}$ (Control group)

Table 2 Plasma TRH, TSH, $\mathrm{T}_{3}$, and $\mathrm{T}_{4}$ levels in P. sicula subjected to $\mathrm{OP}$ and $\mathrm{OP}+\mathrm{NP}$ treatments (see Materials and Methods section)

\begin{tabular}{lclll}
\hline Treatments & TRH $(\mu \mathrm{UI} / \mathrm{mL})$ & $\mathrm{TSH}(\mu \mathrm{UI} / \mathrm{mL})$ & $\mathrm{T}_{3}(\mathrm{ng} / \mathrm{mL})$ & $\mathrm{T}_{4}(\mathrm{ng} / \mathrm{mL})$ \\
\hline Control time 0 & $3.15 \pm 0.16$ & $7.23 \pm 0.04$ & $5.21 \pm 0.10$ & $6.18 \pm 0.05$ \\
Control with oil & $3.19 \pm 0.14$ & $7.24 \pm 0.02$ & $5.22 \pm 0.08^{* * *}$ & $6.14 \pm 0.08$ \\
OP & & & \\
Group I & $8.03 \pm 0.05^{* * *}$ & $3.21 \pm 0.06^{* * *}$ & $1.22 \pm 0.02^{* * *}$ & $1.46 \pm 0.02^{* * *}$ \\
Group II & $8.48 \pm 0.11^{* * *}$ & $1.98 \pm 0.05^{* * *}$ & $1.00 \pm 0.05^{* * *}$ & $2.43 \pm 0.03 * * *$ \\
Group III & $7.15 \pm 0.15^{* * *}$ & $2.15 \pm 0.10^{* * *}$ & $1.26 \pm 0.01^{* * *}$ & $1.55 \pm 0.02^{* * *}$ \\
OP + NP & & & & \\
Group IV & $9.23 \pm 0.46^{* * *}$ & $1.41 \pm 0.07 * * *$ & $1.01 \pm 0.05^{* * *}$ & $0.98 \pm 0.05^{* * *}$ \\
Group V & $10.2 \pm 0.51^{* * *}$ & $1.01 \pm 0.05^{* * *}$ & $0.93 \pm 0.04 * * *$ & $0.45 \pm 0.02 * * *$ \\
Group VI & $4.15 \pm 0.21^{*}$ & $1.63 \pm 0.08^{* * *}$ & $1.15 \pm 0.06^{* * *}$ & $1.36 \pm 0.07 * * *$ \\
\hline
\end{tabular}

Asterisks indicate statistically significant differences from the control group $\left({ }^{*} p<0.05,{ }^{* * *} p<0.001\right)$
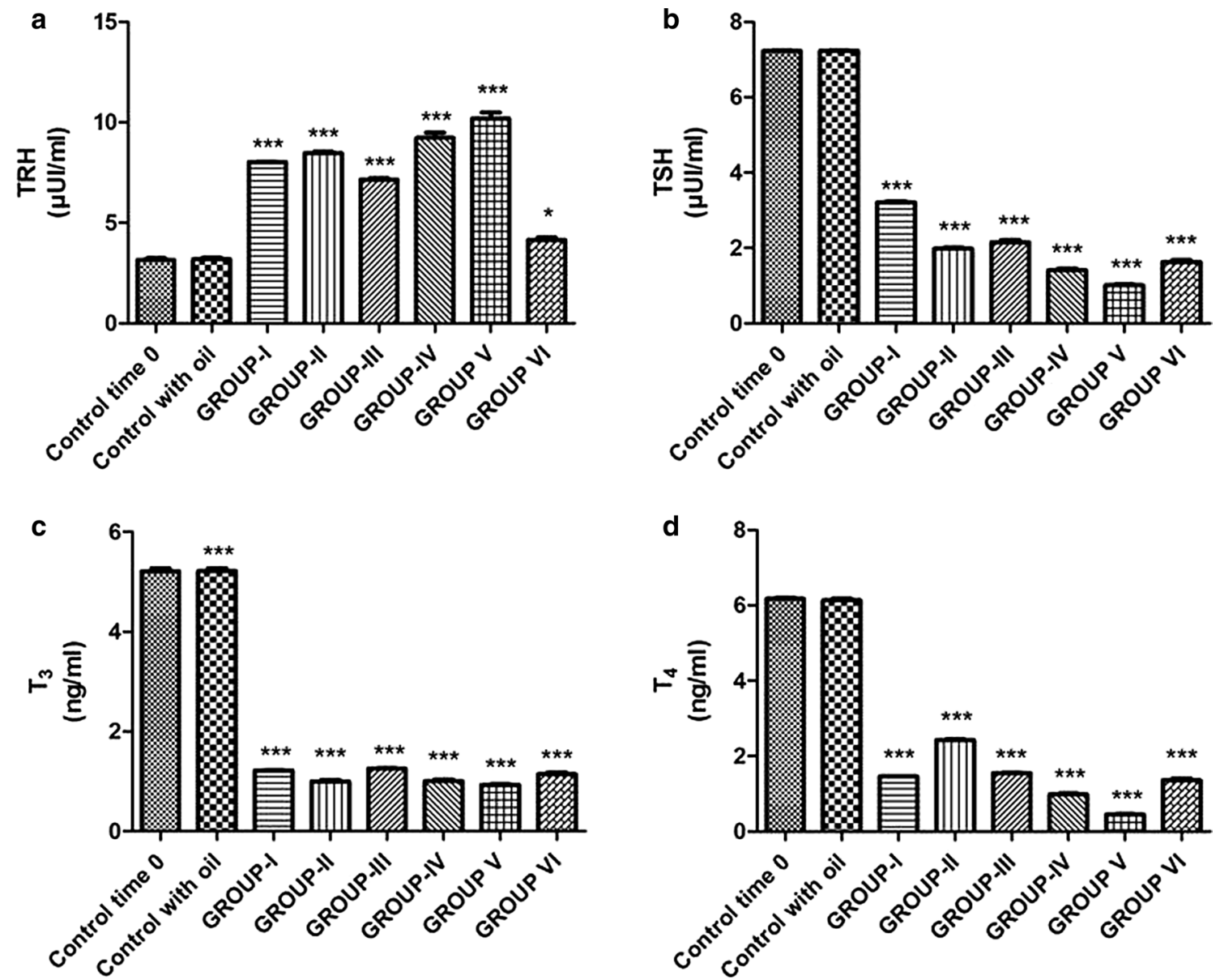

Fig. 1 Plasma levels of TRH (a), TSH $(\mathbf{b}), \mathrm{T}_{3}(\mathbf{c}), \mathrm{T}_{4}(\mathbf{d})$ after OP and OP $+\mathrm{NP}$ treatments $(* p<0.05$, $* * * p<0.001$, in the comparison with the control). A more detailed description in the text 
to $1.46 \pm 0.07 \mathrm{ng} / \mathrm{mL}$ (Group I) (Table 2; Fig. 1c, d), which is in accordance with the decreased level of TSH.

As previously noticed, the hormonal fluctuation seemed to depend on the duration of the treatment. An even further increase in TRH plasma level $(8.48 \pm 0.42 \mu \mathrm{UI} / \mathrm{mL})$, and decrease in TSH plasma levels $(1.98 \pm 0.10 \mu \mathrm{UI} / \mathrm{mL})$ were observed in the specimens treated with 22 injections of OP (Study Group II) (Table 2; Fig. 1a, b). Similarly, $\mathrm{T}_{3}$ and $\mathrm{T}_{4}$ passed to the value of $1.00 \pm 0.05 \mathrm{ng} / \mathrm{mL}$ and $2.43 \pm 0.12 \mathrm{ng} /$ $\mathrm{mL}$, respectively (Study Group II) (Table 2; Fig. 1c, d).

Concentration of hormones of HPT axis was reversed in specimens treated with 22 injections of OP and sacrificed 15 days after the last injection (recovery OP group-Study Group III). In particular, a lesser increase of TRH levels was observed $(7.15 \pm 0.36 \mu \mathrm{UI} / \mathrm{mL}$; Study Group III), but this was still significantly higher than the level recorded in the control specimens $(3.15 \pm 0.16 \mu \mathrm{UI} / \mathrm{mL})$ (Table 2; Fig. 1a). The pituitary hormone (TSH) and the thyroid hormones $\left(\mathrm{T}_{3}\right.$ and $\mathrm{T}_{4}$ ) also inverted the trend observed during the treatment, but similarly to TRH levels, these values remained still higher than those of the control group. In particular, increased TSH plasma levels reached $2.15 \pm 0.11 \mu \mathrm{UI} / \mathrm{mL}$ (Table 2; Fig. 1b) and $\mathrm{T}_{3}$ and $\mathrm{T}_{4}$ were $1.26 \pm 0.06 \mathrm{ng} / \mathrm{mL}$ and $1.55 \pm 0.07 \mathrm{ng} / \mathrm{mL}$, respectively (Study Group III) (Table 2; Fig. 1c, d).

Biochemical data showed that Podarcis siculus thyroid secretory activity was inhibited after treatment with the mixture of OctylPhenol and NonylPhenol (Table 2).

Particularly, plasma levels of the hypothalamic factor TRH increased reaching the value of $9.23 \pm 0.46 \mu \mathrm{UI} / \mathrm{mL}$ (Study Group IV) after 10 injections of OP $+\mathrm{NP}$, being three times higher than control group value $(3.15 \pm 0.16 \mu \mathrm{UI} / \mathrm{mL})$ (Table 2; Fig. 1a). On the contrary, the plasma levels of the pituitary hormone TSH $(1.41 \pm 0.07 \mu \mathrm{UI} / \mathrm{mL})$ (Table 2 ; Fig. 1b) and of the thyroid hormones $\mathrm{T}_{3}(1.01 \pm 0.05 \mathrm{ng} /$ $\mathrm{mL}$ ) and $\mathrm{T}_{4}(0.98 \pm 0.05 \mathrm{ng} / \mathrm{mL}$ ) (Study Group IV) were significantly reduced compared with the values recorded in the control group (TSH: $7.23 \pm 0.36 \mu \mathrm{UI} / \mathrm{mL} ; \mathrm{T}_{3}$ : $5.21 \pm 0.26 \mathrm{ng} / \mathrm{mL} ; \mathrm{T}_{4}: 6.18 \pm 0.31 \mathrm{ng} / \mathrm{mL}$ ) (Table 2; Fig. $1 \mathrm{c}$, d).

This inhibitory effect was even more prominent in the specimens treated with 17 injections of OP + NP (Study Group V) where TRH increased up to $10.2 \pm 0.51 \mu \mathrm{UI} /$ $\mathrm{mL}$, and TSH, $\mathrm{T}_{3}$, and $\mathrm{T}_{4}$ decreased to $1.01 \pm 0.05 \mu \mathrm{UI} / \mathrm{mL}$, $0.93 \pm 0.04 \mathrm{ng} / \mathrm{mL}$, and $0.45 \pm 0.02 \mathrm{ng} / \mathrm{mL}$, respectively (Table 2; Fig. 1a-d).

Lizards treated with 17 injections of the mixture $\mathrm{OP}+\mathrm{NP}$ and sacrificed 15 days after the last injection (Study Group VI-recovery OP + NP group) were characterized by a reduction in TRH plasma levels $(4.15 \pm 0.21 \mu \mathrm{UI} / \mathrm{mL})$ and an increased TSH $(1.63 \pm 0.08 \mu \mathrm{UI} / \mathrm{mL}), \mathrm{T}_{3}(1.15 \pm 0.06 \mathrm{ng} /$ $\mathrm{mL})$, and $\mathrm{T}_{4}(1.36 \pm 0.07 \mathrm{ng} / \mathrm{mL})$ plasma levels, although these values remained higher than those recorded in the control group (Table 2; Fig. 1a-d).

\section{Hepatic Thyroid Hormones Content and 5-T4 ORD (type II) Monodeiodinase Activity}

Lizards treated with OP had a higher liver $\mathrm{T}_{3}$ concentration and 5'ORD (type II) activity, whereas $\mathrm{T}_{4}$ concentration was lower than that of control lizards (Table 3; Fig. 2a-c). An increase of 5'ORD (type II) activity was observed in lizards exposed to 12 injections of OP (Study Group I) $\left(4.06 \pm 0.05 \mathrm{pM} \mathrm{T}_{3} / \mathrm{g} / \mathrm{h}\right)$ and 22 injections of OP both after $24 \mathrm{~h}(4.99 \pm 0.04 \mathrm{pM} \mathrm{T3/g} / \mathrm{h})$ (Study Group II) than that detected 15 days after the last injections $(5.03 \pm 0.04 \mathrm{pM}$ $\mathrm{T}_{3} / \mathrm{g} / \mathrm{h}$ ) (Study Group III) (Table 3; Fig. 2c). A more significant increase of 5'ORD (type II) activity was observed in lizards treated with 17 injections of a mixture of $\mathrm{OP}+\mathrm{NP}$ and sacrificed 15 days after the last injections (Study Group VI) $\left(5.98 \pm 0.14 \mathrm{pM} \mathrm{T}_{3} / \mathrm{g} / \mathrm{h}\right)$ (Table 3; Fig. 2c).
Table 3 Hepatic $\mathrm{T}_{3}, \mathrm{~T}_{4}$ content and monodeiodinase activity (type II) levels in P. sicula subjected to $\mathrm{OP}$ and $\mathrm{OP}+\mathrm{NP}$ treatments (see Materials and Methods section)

\begin{tabular}{llll}
\hline Treatments & $\begin{array}{l}\mathrm{T}_{3}(\mathrm{ng} / \mathrm{mg} \text { of tissue fresh } \\
\text { weight) }\end{array}$ & $\begin{array}{l}\mathrm{T}_{4}(\mathrm{ng} / \mathrm{mg} \text { of tissue fresh } \\
\text { weight) }\end{array}$ & $\begin{array}{l}5 \text { 'ORD II monodeiodi- } \\
\text { nase activity }(\mathrm{pM} \mathrm{T} / \mathrm{g} \\
\text { /h) }\end{array}$ \\
\hline Control time 0 & $3.15 \pm 0.05$ & $4.89 \pm 0.05$ & $3.89 \pm 0.08$ \\
Control with oil & $3.22 \pm 0.04$ & $4.95 \pm 0.06$ & $3.98 \pm 0.07$ \\
OP & & & \\
Group I & $3.72 \pm 0.04 * * *$ & $4.52 \pm 0.06 * * *$ & $4.06 \pm 0.05 * * *$ \\
Group II & $4.96 \pm 0.05^{* * *}$ & $2.25 \pm 0.02 * * *$ & $4.99 \pm 0.04 * * *$ \\
Group III & $5.12 \pm 0.05^{* * *}$ & $2.96 \pm 0.02 * * *$ & $5.03 \pm 0.04 * * *$ \\
OP + NP & & & $4.98 \pm 0.05 * * *$ \\
Group IV & $4.44 \pm 0.06^{* * *}$ & $3.12 \pm 0.04 * * *$ & $5.54 \pm 0.04 * * *$ \\
Group V & $4.96 \pm 0.05^{* * *}$ & $2.89 \pm 0.03 * * *$ & $5.98 \pm 0.14 * * *$ \\
Group VI & $5.95 \pm 0.05^{* * *}$ & $2.32 \pm 0.05 * * *$ & \\
\hline
\end{tabular}

Asterisks indicate statistically significant differences from the control group $(* * * p<0.001)$ 

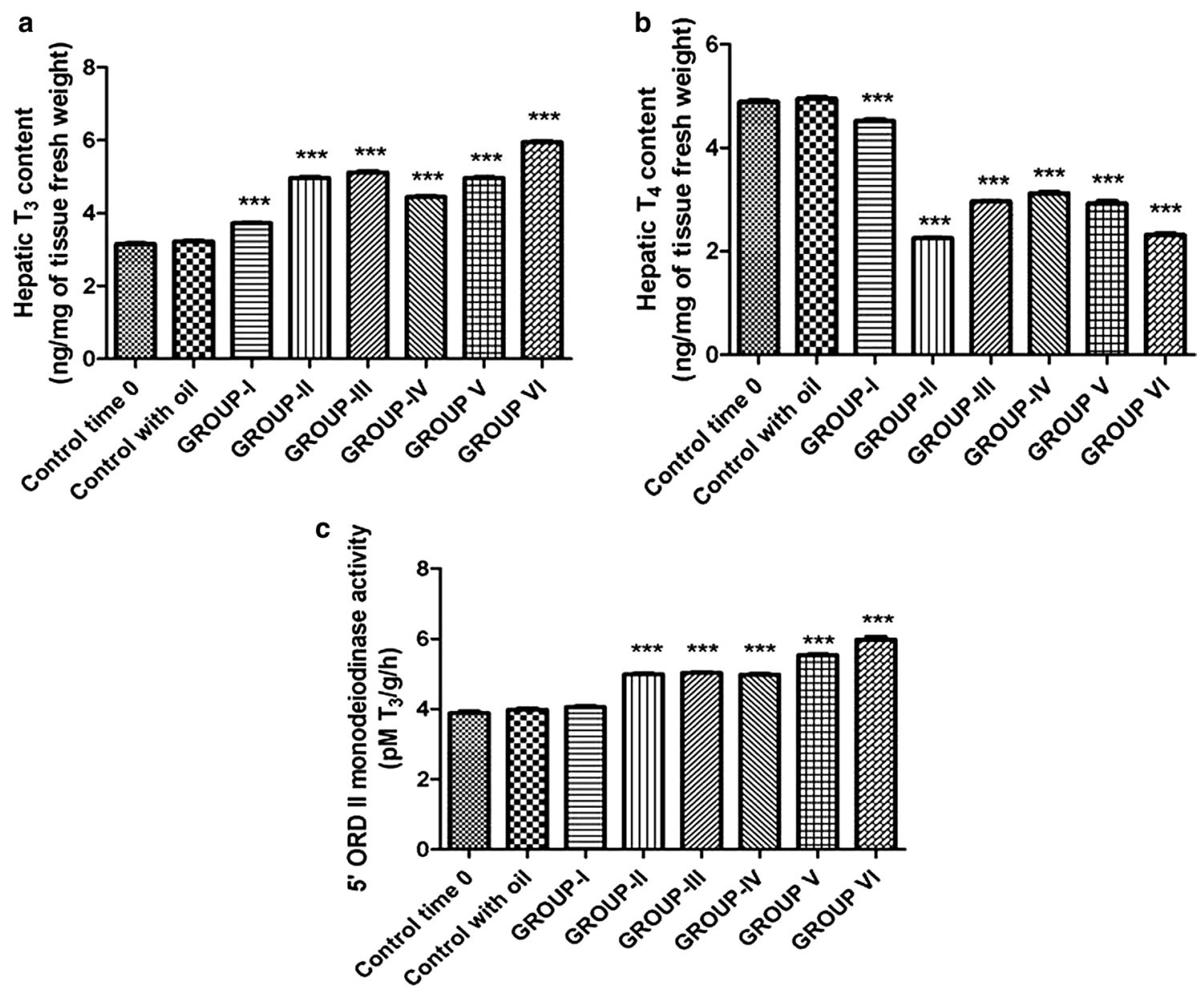

Fig. 2 Hepatic content of $\mathrm{T}_{3}$ (a), $\mathrm{T}_{4}$ (b), 5'ORD II monodeiodinase activity (c) after OP and OP $+\mathrm{NP}$ treatments $(* * * p<0.001$, in the comparison with the control). A more detailed description in the text

Hepatic $\mathrm{T}_{3}$ increases both in the lizards treated with $\mathrm{OP}$ and in those treated with $\mathrm{OP}+\mathrm{NP}$, being particularly high in animals belonging to study group VI $(5.95 \pm 0.05 \mathrm{ng} /$ $\mathrm{mg}$ of tissue fresh weight) compared with the controls $(3.15 \pm 0.05 \mathrm{ng} / \mathrm{mg}$ of tissue fresh weight) (Table 3; Fig. 2a). On the contrary, the hepatic contents of $\mathrm{T}_{4}$ decreased in all groups treated with $\mathrm{OP}$ and $\mathrm{OP}+\mathrm{NP}$, becoming especially low in animals treated with 17 injections of OP $+\mathrm{NP}$ and sacrificed 15 days after the last injection (Group VI- recovery OP + NP group) $(2.32 \pm 0.05 \mathrm{ng} / \mathrm{mg}$ of tissue fresh weight) (Table 3; Fig. 2b).

\section{Thyroid Gland Histology After Treatments}

The thyroid gland transversely crosses the middle of the trachea in Podarcis siculus specimens, looking like a ribbonshaped structure consisting of follicles that are connected to each other by an interfollicular connective tissue that holds blood vessels. The gland is wrapped in a capsule of superficial connective tissue that branches out and forms a network that surrounds the follicles. Each follicle is enveloped in a high cuboidal epithelium (15.1 $\pm 0.02 \mu \mathrm{m})$ (Table 4; Fig. 3), formed by thyrocytes and containing a medium-sized colloidal mass (Fig. 4a).

The thyroid gland of lizards treated with 12 injections of OP appeared richly vascularized with a medium follicular epithelium (12.5 $\pm 0.03 \mu \mathrm{m})$ (Table 4; Fig. 3); thyrocytes had still a cubic shape and colloid showed numerous reabsorption vacuoles (Fig. 4b). After 22 injections of OP, lizards showed a thyroid gland with a lower follicular epithelium $(4.51 \pm 0.04 \mu \mathrm{m})$ (Table 4; Fig. 3) and a retracted colloid without reabsorption vacuoles (Fig. 4c). Morphologically, in specimens treated with 22 injection of OP and sacrificed 15 days after the last injections (recovery OP group), there was no histological sign of recovery, which is in contrast to what was observed from a hormonal point of view (Fig. 4d).

Morphological analysis of the thyroid gland in specimens treated with 10 injections of the mixture OP $+\mathrm{NP}$ showed a slight reduction in the height of the follicular epithelium and a partial retroaction of the colloid 
Table 4 Variations of epithelium height of the follicular cells of the thyroid gland in P. sicula subjected to $\mathrm{OP}$ and $\mathrm{OP}+\mathrm{NP}$ treatments (see Materials and Methods section)

\begin{tabular}{ll}
\hline Treatments & $\begin{array}{l}\text { Height of follicular } \\
\text { epithelium }(\mu \mathrm{m})\end{array}$ \\
\hline Control time 0 & $15.1 \pm 0.02$ \\
Control with oil & $15.3 \pm 0.05$ \\
OP & \\
Group I & $12.5 \pm 0.03^{* * *}$ \\
Group II & $4.51 \pm 0.04 * * *$ \\
Group III & $3.12 \pm 0.03^{* * *}$ \\
OP+NP & \\
Group IV & $5.01 \pm 0.03^{* * *}$ \\
Group V & $2.50 \pm 0.02^{* * *}$ \\
Group VI & $3.23 \pm 0.05^{* * *}$ \\
\hline
\end{tabular}

Asterisks indicate statistically significant differences from the control Group $(* * * p<0.001)$

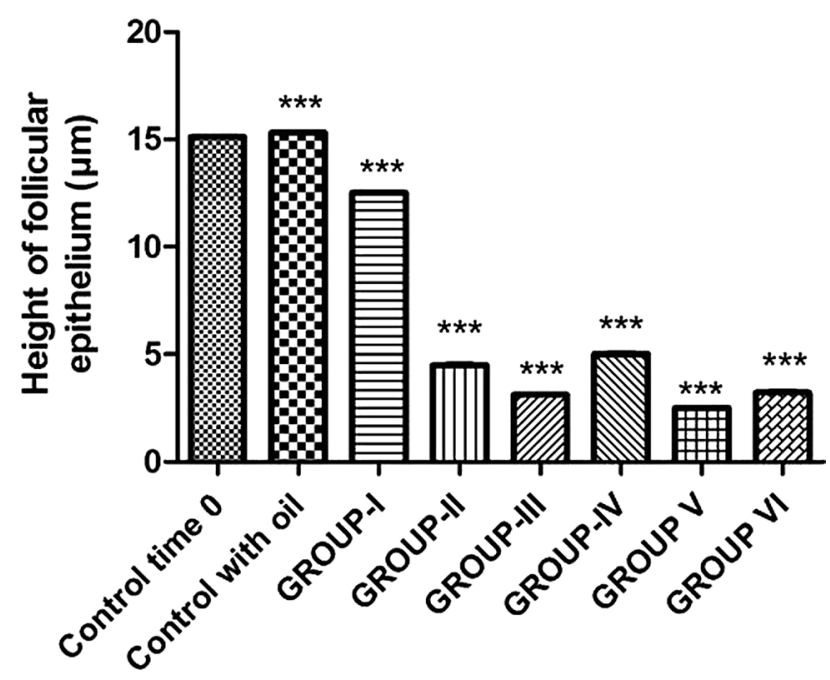

Fig. 3 Height of follicular epithelium after OP and OP + NP treatments $(* * * p<0.001$, in the comparison with the control). A more detailed description in the text

(Fig. 4e), which is in accordance with hormonal dosages results. Overlapping results were observed in the group treated with 17 injections of the mixture $\mathrm{OP}+\mathrm{NP}$ (Fig. 4f). The follicular epithelium was lower than normal $(2.5 \pm 0.02 \mu \mathrm{m})($ Table 4; Fig. 3), and the nuclei of the thyrocytes were small and elongated with dense chromatin and a greatly reduced cytoplasm. The colloid was retracted with few reabsorption vacuoles. The thyroid gland showed very evident signs of a poor functional activity. In the recovery $\mathrm{OP}+\mathrm{NP}$ group, the histological evaluation did not show any signs of recovery of the organism (Fig. $4 \mathrm{~g}$ ).

\section{Discussion}

The release, accumulation, and fate of numerous pollutants in the environment is attracting a lot of attention for its potential negative impact on human health. Several environmental pollutants are classified as endocrine-disrupting chemicals (EDCs) for their potential to disrupt the endocrine system. Thyroid can be a target of different EDCs, which can impair its physiology at different levels, including its central regulatory system in the hypothalamus and pituitary axis, thyroid hormone production and transfer, as well as hormone function, metabolism, and bioavailability (Calsolaro et al. 2017; Mughal et al. 2018).

In the lizard Podarcis siculus, thyroid hormones (THs) production is primarily regulated by two components: "central control" and "peripheral control" (Sciarrillo et al. 2000). Under the central control, the thyroid-stimulating hormone (TSH), a glycoprotein secreted by the anterior pituitary gland, regulates the synthesis and release of THs by the thyroid follicles. In lizards, 3,3',5,5'-L-thyroxine $\left(\mathrm{T}_{4}\right)$ is the predominant thyroid follicle secretion (Sciarrillo et al. 2000); it has strong negative feedback effects on TSH levels. $\mathrm{T}_{4}$ is transported to the peripheral tissues (e.g., liver) via the circulatory system and is either converted to the more bioactive $3,3^{\prime}, 5$-triiodo-L-thyronine $\left(\mathrm{T}_{3}\right)$ or to the inactive degradation products by iodothyronine deiodinase (type II, D2) under peripheral regulation. The primary control of $\mathrm{T}_{3}$ levels is known to occur mainly in peripheral tissues (Sciarrillo et al. 2000). THs exert their physiological effects mainly by interacting with the nuclear thyroid receptors (TRs), which belong to a large super-family of ligand-induced transcription factors (Virgilio et al. 2004).

To date, few investigations have been conducted about the effects of alkylphenols on the thyroid gland. Therefore, in this study we have evaluated the impact of OP as such or in combination with NP on the thyroid gland of the lizards Podarcis siculus in vivo. Our results indicate that treatment with both compounds cause structural and functional alterations in the thyroid gland of the lizards. In particular, OP and OP + NP treatments caused a strong time- and dose-dependent inhibition of the functionality of the gland, which is in line with what we previously reported for NP treatment (Sciarrillo et al. 2010).

Functionally, OP and OP + NP treatments might cause hypothyroidism as they determine a secretory blockage in the pituitary gland. This conclusion emerged from the analysis of biochemical data that showed an increase in TRH levels and a decrease in the hormones TSH, $\mathrm{T}_{3}$, and $\mathrm{T}_{4}$ following both treatments.

Structurally, lizards exposed to OP and OP $+\mathrm{NP}$ showed a reduced height of the follicular epithelium and a retracted colloid with fewer reabsorption vacuoles. 


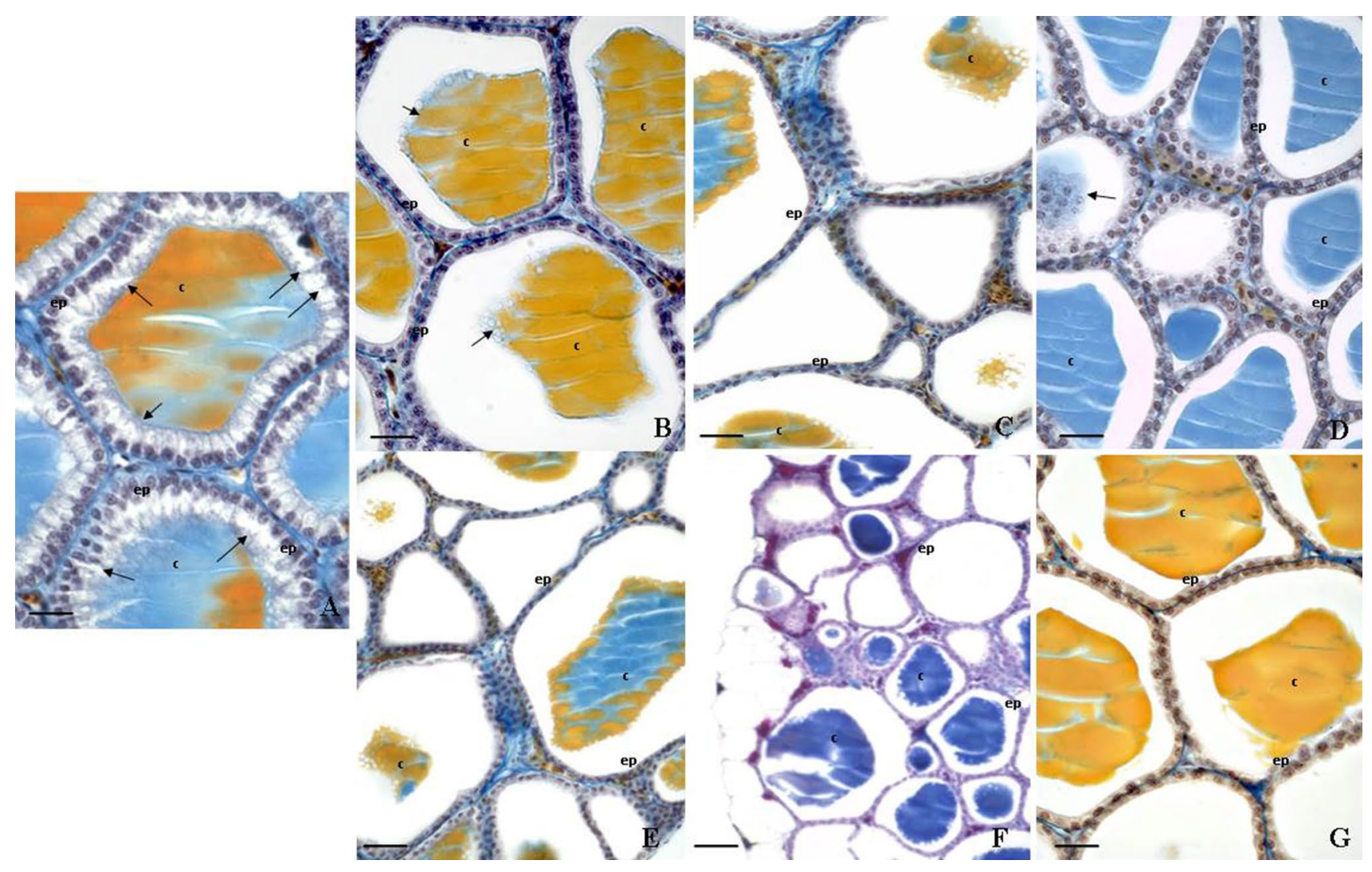

Fig. 4 Thyroid gland of lizard's P. siculus (stain Galgano I); Scale bar: $20 \mu \mathrm{m}$. a Control lizard: the cuboidal follicular epithelial cells (ep), the colloid (c), and the reabsorption vacuoles (arrow) are shown. b Lizards treated with OP for 12 days and sacrificed $24 \mathrm{~h}$ after the last injection: the follicular epithelium (ep) is lower than in control animals. c Lizards treated with OP for 22 days and sacrificed $24 \mathrm{~h}$ after the last injection: the follicular epithelium (ep) is very low and the decrease of colloids (c) in follicles is very evident compared with untreated animals. d Lizards treated with OP for 22 days and sacrificed 15 days after the last injection (recovery OP group): the follicular epithelium (ep) is lower than normal, but the colloid (c) is pre-

Follicular epithelium height and colloid are indices of secretory activity of the gland (Movahedinia et al. 2018) as well as useful parameters for the observation of EDC morphological effects on the thyroid. Moreover, epithelial cell height is a histological method of thyroid gland assessment as it is considered to be roughly proportional to the degree of response to thyroid-stimulating hormone (TSH) (Moccia et al. 1981). In this study, OP and OP + NP induced a decrease in the height of thyroid follicular cells, follicular cell hyperplasia, shrunken follicular epithelial cells, and decreased cytoplasm quantity in the thyroid gland. These observation suggest that EDCs could influence the microscopic structures of the thyroid gland. In addition, it is possible to speculate that the HPT axis may be targeted by AlkylPhenolic compounds, such as OP, alone or in combination with NP. sent in the follicles. e Lizards treated with $\mathrm{OP}+\mathrm{NP}$ for 10 days and sacrificed $24 \mathrm{~h}$ after the last injection: the follicular epithelium (ep) is lower than normal and no reabsorbing vacuoles are visible in the colloid (c). f Lizards treated with OP + NP for 17 days and sacrificed $24 \mathrm{~h}$ after the last injection: the follicular epithelium (ep) is very low compared with normal epithelium, and no reabsorbing vacuoles can be seen in the colloid (c). g Lizards treated with OP + NP for 17 days and sacrificed 15 days after the last injection (recovery $\mathrm{OP}+\mathrm{NP}$ group); the follicular epithelium (ep) is lower than normal epithelium, but the colloid (c) is present in the follicles

Our results confirm the inverse association between APs doses and circulating levels of thyroid hormones in Podarcis siculus lizards. The thyroid function is regulated by sensitive feedback mechanisms of circulating thyroid hormones at the hypothalamic (TRH) and pituitary levels (TSH). The appropriate response of the feedback would result in declined/ reduced TSH levels, which might result in compensatory hypoplasia of thyroid tissue. Histopathological changes that we observed in all treated animals suggest the possible effects of APs on feedback mechanisms of HypothalamicPituitary-Thyroid (HPT) axis (Santos-Silva et al. 2018; Sheikh 2020; Xie et al. 2019).

Despite advances in analytical methods to study these chemicals in biological tissues, the identification of reliable markers to measure the effects of APs on thyroid function, the exact way, and/or mechanisms of action remains still 
difficult. APs may interfere with TH homeostasis in different ways. Many of the physiological functions of tissue cells (i.e., liver) depend on the dynamic regulation of THs and therefore the iodothyronine deiodinase is critical to this regulation. Hepatic 5'ORD (Type II) activity in all treated groups was significantly higher than in the control group, along with a decreased $\mathrm{T}_{4}$ and an increased $\mathrm{T}_{3}$ contents. Based on these observations, we hypothesize that reduction of liver $\mathrm{T}_{4}$ content is dependent on the down-regulation of 5 'ORD (Type II) after exposure to APs. These results indicate that APs could induce an abnormal thyroid function by influencing levels of deiodinases in peripheral tissues (i.e., liver) and TRs. Environmental APs might enhance the metabolic rate of TH in vivo by inhibiting binding of THs to TRs, thus causing a decrease in TH activity and an increase in iodothyronine deiodinase activity. Inhibition of TH-binding by OP might damage the TRH-TSH-THs regulatory pathway. In addition, APs might accelerate the TH metabolic rate by enhancing the activity of iodothyronine deiodinase, leading to a decrease in $\mathrm{T}_{3}$ and $\mathrm{T}_{4}$ activity (He et al. 2020).

APs might influence TH activity via the regulation of multiple targets within the complex regulatory network of TH metabolism and activity, including TRs binding and activation. This mechanism mediates gene regulation in response to $\mathrm{T}_{3}$ deiodinase, which catalyzes deiodination of $\mathrm{T}_{4}$ to be converted to the biologically active $\mathrm{T}_{3}$ form, and the Hypothalamus-Pituitary-Thyroid axis, which contains the TRH-TSH-THs negative feedback (Street et al. 2018).

\section{Conclusions}

Our results suggest that EDCs and in particular APs interfere with thyroid function in P. siculus at different levels, including the central regulatory system in the hypothalamus and pituitary, thyroid hormone production at the thyroid gland, thyroid hormone transfer, as well as hormone bioavailability, function, and metabolism in peripheral organs.

Funding This work was supported by Research funds of University of Sannio.

\section{Declaration}

Conflict of interest Authors declare no conflicts of interest or competing interests.

Open Access This article is licensed under a Creative Commons Attribution 4.0 International License, which permits use, sharing, adaptation, distribution and reproduction in any medium or format, as long as you give appropriate credit to the original author(s) and the source, provide a link to the Creative Commons licence, and indicate if changes were made. The images or other third party material in this article are included in the article's Creative Commons licence, unless indicated otherwise in a credit line to the material. If material is not included in the article's Creative Commons licence and your intended use is not permitted by statutory regulation or exceeds the permitted use, you will need to obtain permission directly from the copyright holder. To view a copy of this licence, visit http://creativecommons.org/licenses/by/4.0/.

\section{References}

Acconcia F, Fiocchetti M, Marino M (2017) Xenoestrogen regulation of $\mathrm{ER} \alpha / \mathrm{ER} \beta$ balance in hormone-associated cancers. Mol Cell Endocrinol 457:3-12. https://doi.org/10.1016/j.mce.2016.10.033

Ademollo N, Ferrara F, Delise M, Fabietti F, Funari E (2008) Nonylphenol and octylphenol in human breast milk. Environ Int 34(7):984-987. https://doi.org/10.1016/j.envint.2008.03.001

Asimakopoulos AG, Thomaidis NS, Koupparis MA (2012) Recent trends in biomonitoring of bisphenol A, 4-t-octylphenol, and 4-nonylphenol. Toxicol Lett. https://doi.org/10.1016/j.toxle t.2011.07.032

Atamaniuk TM, Kubrak OI, Husak VV, Storey KB, Lushchak VI (2013) The mancozeb-containing carbamate fungicide tattoo induces mild oxidative stress in goldfish brain, liver, and kidney. Environ Toxicol 29:1227-1235. https://doi.org/10.1002/tox.21853

Axelstad M, Boberg J, Nellemann C, Kiersgaard M, Jacobsen PR, Christiansen S, Hougaard KS, Hass U (2011) Exposure to the widely used fungicide mancozeb causes thyroid hormone disruption in rat Dams but no behavioral effects in the offspring. Toxicol Sci 120(2):439-446. https://doi.org/10.1093/toxsci/kfr006

Benedetti M, Zona A, Beccaloni E, Carere M, Comba P (2017) Incidence of breast, prostate, testicular, and thyroid cancer in italian contaminated sites with presence of substances with endocrine disrupting properties. Int J Environ Res Public Health 14:355. https://doi.org/10.3390/ijerph14040355

Calafat AM, Ye X, Wong LY, Reidy JA, Needham LL (2007) Exposure of the U.S. population to bisphenol A and 4-tertiary-Octylphenol: 2003-2004. Environ Health Perspect 116(1):39-44. https://doi. org/10.1289/ehp. 10753

Calsolaro V, Pasqualetti G, Niccolai F, Caraccio N, Monzani F (2017) Thyroid disrupting chemicals. Int J Mol Sci 18:2583. https://doi. org/10.3390/ijms 18122583

De Falco M, Sciarrillo R, Valiante S, Sellitti A, Valentino B, Gay F, Capaldo A, Laforgia V (2010) A preliminary study of cadmium effects on the adrenal gland of the lizard Podarcis sicula. Open Zool J 3:23-29. https://doi.org/10.2174/1874336601003010023

De Falco M, Sellitti A, Sciarrillo R, Capaldo A, Valiante S, Iachetta G, Forte M, Laforgia V (2014) Nonylphenol effects on the HPA axis of the bioindicator vertebrate, Podarcis sicula lizard. Chemosphere 104:190-196. https://doi.org/10.1016/j.chemospher e.2013.11.014

Di Lorenzo M, Barra T, Rosati L, Valiante S, Capaldo A, De Falco M, Laforgia V (2020a) Adrenal gland response to endocrine disrupting chemicals in fishes, amphibians and reptiles: a comparative overview. Gen Comp Endocrinol 297:113550. https://doi. org/10.1016/j.ygcen.2020.113550

Di Lorenzo M, Sciarrillo R, Rosati L, Sellitti A, Barra T, De Luca A, Laforgia V, De Falco M (2020b) Effects of alkylphenols mixture on the adrenal gland of the lizard Podarcis sicula. Chemosphere 258:127239. https://doi.org/10.1016/j.chemosphere.2020.127239

Djordjevic AB, Antonijevic E, Curcic M, Milovanović V, Biljana A (2020) Endocrine-disrupting mechanisms of polychlorinated biphenyls. Curr Opin Toxicol 19:42-49. https://doi.org/10.1016/j. cotox.2019.10.006

ECHA (2019) n.d. European chemicals agency substance information for Bis(2-ethylhexyl) phthalate [WWW Document]. https://echa. 
europa.eu/substance-information/-/substanceinfo/100.003.829 Accessed 21 May 2020

Esposito T, Varriale B, Irregolare C, Lanza M, Perna A, Paolisso G, Monda M (2015) Correlation between thyroid endocrine status, change in body weight and macular thickness in obese patients. Gen Med 3:5. https://doi.org/10.4172/2327-5146.1000206

Esposito T, Lucariello A, Hay E, Contieri M, Tammaro P, Varriale B, Guerra G, De Luca A, Perna A (2019) Effects of curcumin and its adjuvant on TPC1 thyroid cell line. Chem Biol Interact 305:112-118. https://doi.org/10.1016/j.cbi.2019.03.031

Fernandez MO, Bourguignon NS, Arocena P, Rosa M, Libertun C, Lux-Lantos V (2018) Neonatal exposure to bisphenol A alters the hypothalamic-pituitary-thyroid axis in female rats. Toxicol Lett 285:81-86. https://doi.org/10.1016/j.toxlet.2017.12.029

Forte M, Di Lorenzo M, Carrizzo A, Valiante S, Vecchione C, Laforgia V, De Falco M (2016) Nonylphenol effects on human prostate non tumorigenic cells. Toxicology 357-358:21-32. https://doi. org/10.1016/j.tox.2016.05.024

Forte M, Di Lorenzo M, Iachetta G, Mita DG, Laforgia V, De Falco M (2019) Nonylphenol acts on prostate adenocarcinoma cells via estrogen molecular pathways. Ecotoxicol Environ Saf 180:412419. https://doi.org/10.1016/j.ecoenv.2019.05.035

Ghassabian A, Trasande L (2018) Disruption in thyroid signaling pathway: a mechanism for the effect of endocrine-disrupting chemicals on child neurodevelopment. Front Endocrinol (Lausanne). https:// doi.org/10.3389/fendo.2018.00204

Göktekin E, Barlas N (2008) Histopathological effects of 4-tert-octylphenol treatment through the pregnancy period, on the pituitary, adrenal, pancreas, thyroid and parathyroid glands of offspring rats at adulthood. Environ Toxicol Pharmacol 26:199-205. https://doi. org/10.1016/j.etap.2008.03.013

Goldner WS, Sandler DP, Yu F, Hoppin JA, Kamel F, Levan TD (2010) Pesticide use and thyroid disease among women in the agricultural health study. Am J Epidemiol 171:455-464. https://doi. org/10.1093/aje/kwp404

Hay E, Lucariello A, Contieri M, Esposito T, De Luca A, Guerra G, Perna A (2019) Therapeutic effects of turmeric in several diseases: an overview. Chem Biol Interact 310:108729. https://doi. org/10.1016/j.cbi.2019.108729

He Y, Yang J, Huang S, Liu R, Liu H, Zheng D, Huang Q, Yang Y, Liu C (2019) Protective effect of mulberry crude extract against nonylphenol-induced thyroid disruption by inhibiting the activity of deiodinase in rats. Gen Comp Endocrinol 270:90-95. https:// doi.org/10.1016/j.ygcen.2018.10.010

He N, Liu Z, Sun X, Wang S, Liu W, Sun D, Duan S (2020) Phytotoxicity, bioaccumulation, and degradation of nonylphenol in different microalgal species without bacterial influences. Int J Mol Sci 21:1338. https://doi.org/10.3390/ijms21041338

In SJ, Kim SH, Go RE, Hwang KA, Choi KC (2015) Benzophenone-1 and nonylphenol stimulated MCF-7 breast cancer growth by regulating cell cycle and metastasis-related genes via an estrogen receptor $\alpha$-Dependent Pathway. J Toxicol Environ Heal Part A Curr Issues 78:492-505. https://doi.org/10.1080/15287 394.2015.1010464

Ji C, Jin X, He J, Yin Z (2012) Use of TSH $\beta$ :EGFP transgenic zebrafish as a rapid in vivo model for assessing thyroid-disrupting chemicals. Toxicol Appl Pharmacol 262:149-155. https://doi. org/10.1016/j.taap.2012.04.029

Kubrak OI, Atamaniuk TM, Husak VV, Drohomyretska IZ, Storey JM, Storey KB, Lushchak VI (2012) Oxidative stress responses in blood and gills of Carassius auratus exposed to the mancozebcontaining carbamate fungicide Tattoo. Ecotoxicol Environ Saf 85:37-43. https://doi.org/10.1016/j.ecoenv.2012.08.021

Kung TA, Lee SH, Yang TC, Wang WH (2018) Survey of selected personal care products in surface water of coral reefs in Kenting
National Park. Taiwan Sci Total Environ 635:1302-1307. https:// doi.org/10.1016/j.scitotenv.2018.04.115

Liu C, Lai Y, Ouyang J, Yang T, Guo Y, Yang J, Huang S (2017) Influence of nonylphenol and octylphenol exposure on 5-HT, 5-HT transporter, and 5-HT2A receptor. Environ Sci Pollut Res 24:8279-8286. https://doi.org/10.1007/s11356-017-8487-6

Liu H, Huang Q, Sun H, Li J, Lin Q, Wu H, Liu C (2019) Effects of separate or combined exposure of nonylphenol and octylphenol on central 5-HT system and related learning and memory in the rats. Ecotoxicol Environ Saf 172:523-529. https://doi.org/10.1016/j. ecoenv.2019.02.007

Manente L, Sellitti A, Lucariello A, Laforgia V, De Falco M, De Luca A (2011) Effects of 4-nonylphenol on proliferation of AGS gastric cells. Cell Prolif 44:477-485. https://doi.org/10.111 1/j.1365-2184.2011.00774.x

Moccia RD, Leatherland JF, Sonstegard RA (1981) Quantitative interlake comparison of thyroid pathology in Great Lakes Coho (Oncorhynchus kisutch) and Chinook (Oncorhynchus tschawytscha) Salmon. Cancer Res 41:2200-2210

Moriyama K, Tagami T, Akamizu T, Usui T, Saijo M, Kanamoto N, Hataya Y, Shimatsu A, Kuzuya H, Nakao K (2002) Thyroid hormone action is disrupted by bisphenol A as an antagonist. J Clin Endocrinol Metab 87:5185-5190. https://doi.org/10.1210/ jc.2002-020209

Movahedinia A, Salamat N, Kheradmand P (2018) Effects of the environmental endocrine disrupting compound benzo[a]pyrene on thyroidal status of abu mullet (Liza $a b u$ ) during short-term exposure. Toxicol Rep 5:377-382. https://doi.org/10.1016/j. toxrep.2018.02.018

Mughal BB, Fini JB, Demeneix BA (2018) Thyroid-disrupting chemicals and brain development: an update. Endocr Connect 7:R160-R186. https://doi.org/10.1530/EC-18-0029

Naderi M, Mousavi SM, Safahieh A, Ghatrami ER, Zargham D (2014) Effects of 4-nonylphenol on balance of steroid and thyroid hormones in sexually immature male yellowfin seabream (Acanthopagrus latus). Environ Toxicol 29:459-465. https:// doi.org/10.1002/tox.21772

Perna A, De Luca A, Adelfi L, Pasquale T, Varriale B, Esposito T (2018) Effects of different extracts of curcumin on TPC1 papillary thyroid cancer cell line. BMC Complement Altern Med 18:63. https://doi.org/10.1186/s12906-018-2125-9

Raecker T, Thiele B, Boehme RM, Guenther K (2011) Endocrine disrupting nonyl- and octylphenol in infant food in Germany: considerable daily intake of nonylphenol for babies. Chemosphere 82:1533-1540. https://doi.org/10.1016/j.chemospher e.2010.11.065

Rosati L, Prisco M, Di Lorenzo M, De Falco M, Andreuccetti P (2020) Immunolocalization of aromatase P450 in the epididymis of Podarcis sicula and Rattus rattus. Eur J Histochem 64:32-40. https://doi.org/10.4081/ejh.2020.3080

Santangelo G, Pellino G, De Falco N, Colella G, D’Amato S, Maglione MG, De Luca R, Canonico S, De Falco M (2016) Prevalence, diagnosis and management of ectopic thyroid glands. Int J Surg 28:S1-S6. https://doi.org/10.1016/j.ijsu.2015.12.043

Santos-Silva AP, Andrade MN, Pereira-Rodrigues P, Paiva-Melo FD, Soares P, Graceli JB, Dias GRM, Ferreira ACF, de Carvalho DP, Miranda-Alves L (2018) Frontiers in endocrine disruption: impacts of organotin on the hypothalamus-pituitarythyroid axis. Mol Cell Endocrinol. https://doi.org/10.1016/j. mce.2017.07.038

Sciarrillo R, Laforgia V, Cavagnuolo A, Varano L, Virgilio F (2000) Annual variations of thyroid activity in the lizard Podarcis sicula (squamata, lacertidae). Ital J Zool 67:263-267. https://doi. org/10.1080/11250000009356321

Sciarrillo R, Capaldo A, Valiante S, Laforgia V, De Falco M (2009) Localization and role of galanin in the thyroid gland of Podarcis 
sicula lizard (reptilia, lacertide). J Exp Zool Part A Ecol Genet Physiol 311A:199-206. https://doi.org/10.1002/jez.519

Sciarrillo R, Capaldo A, Valiante S, Gay F, Sellitti A, Laforgia V, De Falco M (2010) Thyroid hormones as potential early biomarkers of exposure to nonylphenol in adult male lizard (Podarcis sicula), Open Zool J

Sheikh IA (2020) Molecular interactions of thyroxine binding globulin and thyroid hormone receptor with estrogenic compounds 4-nonylphenol, 4-tert-octylphenol and bisphenol A metabolite (MBP). Life Sci 253:117738. https://doi.org/10.1016/j.lfs.2020.117738

Shekhar S, Sood S, Showkat S, Lite C, Lite C, Chandrasekhar A, Vairamani M, Barathi S, Santosh W (2017) Detection of phenolic endocrine disrupting chemicals (EDCs) from maternal blood plasma and amniotic fluid in Indian population. Gen Comp Endocrinol 241:100-107. https://doi.org/10.1016/j.ygcen.2016.05.025

Staniszewska M, Graca B, Sokolowski A, Nehring I, Wasik A, Jendzul A (2017) Factors determining accumulation of bisphenol A and alkylphenols at a low trophic level as exemplified by mussels Mytilus trossulus. Environ Pollut 220(Pt B):1147-1159. https:// doi.org/10.1016/j.envpol.2016.11.020

Street M, Angelini S, Bernasconi S, Burgio E, Cassio A, Catellani C, Cirillo F, Deodati A, FabbriziE FV, Gargano G, Grossi E, Iughetti L, Lazzeroni P, Mantovani A, Migliore L, Palanza P, Panzica G, Papini A, Parmigiani S, Predieri B, Sartori C, Tridenti G, Amarri S (2018) Current knowledge on endocrine disrupting chemicals (EDCs) from animal biology to humans, from pregnancy to adulthood: highlights from a national italian meeting. Int J Mol Sci 19:1647. https://doi.org/10.3390/ijms19061647

Tan BLL, Kassim NM, Mohd MA (2003) Assessment of pubertal development in juvenile male rats after sub-acute exposure to bisphenol A and nonylphenol. Toxicol Lett 143:261-270. https ://doi.org/10.1016/S0378-4274(03)00172-3

Tingi E, Syed AA, Kyriacou A, Mastorakos G, Kyriacou A (2016) Benign thyroid disease in pregnancy: a state of the art review. $J$ Clin Transl Endocrinol. https://doi.org/10.1016/j.jcte.2016.11.001

Verderame M, Limatola E, Scudiero R (2016a) Ectopic synthesis of vitellogenin in testis and epididymis of estrogen-treated lizard Podarcis sicula Gen. Comp Endocrinol 235:57-63. https://doi. org/10.1016/j.ygcen.2016.06.012
Verderame M, Limatola E, Scudiero R (2016b) Estrogenic contamination by manure fertilizer in organic farming: a case study with the lizard Podarcis sicula. Ecotoxicology 25(1):105-114. https://doi. org/10.1007/s 10646-015-1571-0

Virgilio F, Sciarrillo R, De Falco M, Comitato R, Laforgia V, Varano L, Cardone A (2004) Temporal expression of thyroid hormone receptor in the liver of the lizard Podarcis sicula. J Exp Zool 301A:212-217. https://doi.org/10.1002/jez.a.20031

Wang L, Xu J, Zeng F, Fu X, Xu W, Yu J (2019) Influence of nonylphenol exposure on basic growth, development, and thyroid tissue structure in F1 male rats. Peer J 7:e7039. https://doi.org/10.7717/ peerj.7039

Wetherill YB, Akingbemi BT, Kanno J, McLachlan JA, Nadal A, Sonnenschein C, Watson CS, Zoeller RT, Belcher SM (2007) In vitro molecular mechanisms of bisphenol A action. Reprod Toxicol. https://doi.org/10.1016/j.reprotox.2007.05.010

Xi Y, Li D, San W (2013) Exposure to the endocrine disruptor nonylphenol alters structure and function of thyroid gland in rats. Regul Pept 185:52-56. https://doi.org/10.1016/j.regpep.2013.06.004

Xie L, Li X, Liang K, Wu C, Wang HY, Zhang Y (2019) Octylphenol influence growth and development of Rana chensinensis tadpoles via disrupting thyroid function. Ecotoxicol Environ Saf 169:747755. https://doi.org/10.1016/j.ecoenv.2018.11.083

Zizza M, LorenzoM Di, Laforgia V, Furia E, Sindona G, Canonaco M, Facciolo RM (2017) HSP90 and pCREB alterations are linked to mancozeb-dependent behavioral and neurodegenerative effects in a marine teleost. Toxicol Appl Pharmacol 323:26-35. https://doi. org/10.1016/j.taap.2017.03.018

Zizza M, Di Lorenzo M, Laforgia V, Furia E, Sindona G, Canonaco M, Facciolo RM (2018) Orexin receptor expression is increased during mancozeb-induced feeding impairments and neurodegenerative events in a marine fish. Neurotoxicology 67:46-53. https ://doi.org/10.1016/j.neuro.2018.04.010

Zoeller RT, Bansal R, Parris C (2005) Bisphenol-A, an environmental contaminant that acts as a thyroid hormone receptor antagonist in vitro, increases serum thyroxine, and alters RC3/Neurogranin expression in the developing rat brain. Endocrinology 146:607612. https://doi.org/10.1210/en.2004-1018 